\title{
Assessing the suitability of new film laminates for sustainable insect eradication by modified atmosphere in museums
}

\author{
Manar M. Elkhial ${ }^{1 *}$ (1) and Nesrin M. N. El Hadidi ${ }^{2}$
}

\begin{abstract}
The increasing demand for applying modified inert atmosphere systems for insect eradication in museums has led to the desire for lower-cost consumable materials, particularly laminated plastic films. An ultra-low oxygen-permeable laminate is required for creating successful systems of modified inert atmosphere to keep the oxygen concentration lower than $0.3 \%$. A range of ultra-high barrier laminates is commercially available but at a high cost, which could affect the sustainability of applying these systems in museums of limited budgets. The wide use of local laminates for food preservation makes them a perfect target for testing and improvement as alternatives. However, a laboratorial test method for evaluating their oxygen permeability is required to assess their suitability for insect eradication using modified atmospheres. Therefore, the present work investigates the potential of using two laminates (one local and one imported) to create a successful modified atmosphere system. A laboratory easy-to-use test method was used to assess the oxygen permeability of each laminate and calculate its oxygen transmission rate. The test method is a sealed static chamber separated in the middle by a known area of the laminate to be tested. The test relies on monitoring the change of oxygen concentration overtime on either side of the laminate membrane within the sealed system to assess its oxygen transmission rate. The specifications and design of the test chamber are adopted from the ASTM Designation: E2945 - 14. Results indicated that the new method is useful for an unlimited number of tests of an unlimited number of laminates. The conducted tests proved that the local laminate normally used for food packaging showed good results in terms of its oxygen transmission rate.
\end{abstract}

Keywords: Plastic film, Oxygen transmission rate, Insect disinfestation, Museums pests, Permeability test, ESCAL, Nylon, Cross-barrier, Low-oxygen

\section{Introduction}

The preservation of cultural and historical collections from insect attack is a challenging task, as insects still are a primary cause of loss of heritage materials [1]. Modified inert atmospheres (MIAs) where oxygen is intentionally reduced by an inert gas [2] are widely used for eradicating insect pests [3-6], significantly slow decay processes [7], and allow for long-term preservation of heritage objects

\footnotetext{
*Correspondence: manar_el_khial@yahoo.com

${ }^{1}$ Conservation Center, The Grand Egyptian Museum, Al Haram, Giza Governorate, Egypt

Full list of author information is available at the end of the article
}

$[8,9]$ since the 1990s [1]. The treatment can be applied in rigid chambers, portable bubbles, or low-permeability plastic bags [10]. The use of flexible plastic bags that fit the shape and size of the infested collection is generally a practical solution [11]. The plastic films used to create MIA bags must meet some criteria. A typical film must be flexible to easily create custom-made bags or tents, heat sealable to one another at a surface temperature not affecting the surface of the other laminate, non-puncturable or non-scratchable, transparent enough to see the artifacts through them, low permeable to oxygen, and available at low cost to ensure sustainable application of the treatment.

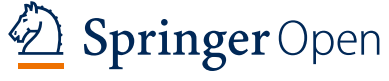

(c) The Author(s) 2022 Open Access This article is licensed under a Creative Commons Attribution 4.0 International License, which permits use, sharing, adaptation, distribution and reproduction in any medium or format, as long as you give appropriate credit to the original author(s) and the source, provide a link to the Creative Commons licence, and indicate if changes were made. The images or other third party material in this article are included in the article's Creative Commons licence, unless indicated otherwise in a credit line to the material. If material is not included in the article's Creative Commons licence and your intended use is not permitted by statutory regulation or exceeds the permitted use, you will need to obtain permission directly from the copyright holder. To view a copy of this licence, visit http://creativecommons.org/licenses/by/4.0/. The Creative Commons Public Domain Dedication waiver (http://creativeco mmons.org/publicdomain/zero/1.0/) applies to the data made available in this article, unless otherwise stated in a credit line to the data. 
The properties of single-layer plastic films are affected by many factors, for example the chemical nature of the film polymer, the distribution and concentration of its molecules, and the fabrication process itself [12]. Although additives are used for optimizing some properties [13-15] or adding new ones to plastic films [15-19], no physical or chemical modifications resulted in a perfect, single-layer film that meets all the requirements for MIA applications [12]. Therefore, laminated films of special properties are used for MIA purposes. The MIA laminate is normally composed of three layers of polymer films [15, 20]: an internal heat-sealable layer [21, 22], an oxygen barrier layer [11], and a protective outer layer. However, there is not yet a perfect laminate that fulfills all the required criteria for MIA applications [12], and the selection of the suitable laminate depends generally on its oxygen transmission rate (OTR) as the key factor for MIA effectiveness. OTR is often expressed as the amount of oxygen gas $\left(\mathrm{cm}^{3}\right)$ that can pass through a square meter of the film membrane in one day [23-25]. Nowadays, a wide variety of laminates are industrially available and commonly used for MIA treatments worldwide for their low OTR (Fig. 1). Most of these laminates are very expensive and are produced by companies located mainly in the United States, Japan, and Germany, and must therefore be imported, which might restrict their use and double their costs.

Depending on expensive laminates might therefore question the sustainability of applying MIA treatments in flexible bags in museums of limited budgets, and there is a need to look for local alternatives to decrease the cost and guarantee sustainability. Fortunately, the food packaging industry yields a huge number of different local laminates. The only problem associated with their use is that their OTR might generally be unknown and they, therefore, need to be tested to assess their suitability for MIA applications. Automated permeability test devices that can be compatible with ultra-low permeable laminates might not be locally available. In 2001, a quick, reliable test method for measuring the transferred mass of the fumigants through plastic films was presented by Papiernik, et al. [26]. The method has been proved reliable and valid in testing low-permeable polyethylene films $[27,28]$ and was later standardized and approved by ASTM in 2014 [29] and updated in 2021 [30]. Accordingly, this study adopted and developed the standard test to provide an accurate method that could be easily applied in a museum laboratory to choose between the MIA laminates. The methodological approach has been used to assess the suitability of different laminates through measuring their OTR attempting to find alternatives to the expensive laminates to ensure the sustainability of applying MIA treatments in museums.

\section{Materials and methods \\ Plastic films}

Three film laminates were selected in this study for measuring their oxygen permeability and OTR: a well-known MIA laminate, ESCAL ${ }^{\mathrm{TM}}$, and a local laminate in Japan, Cross-Barrier $^{\mathrm{TM}}$, and a local laminate in Egypt, Nylon.

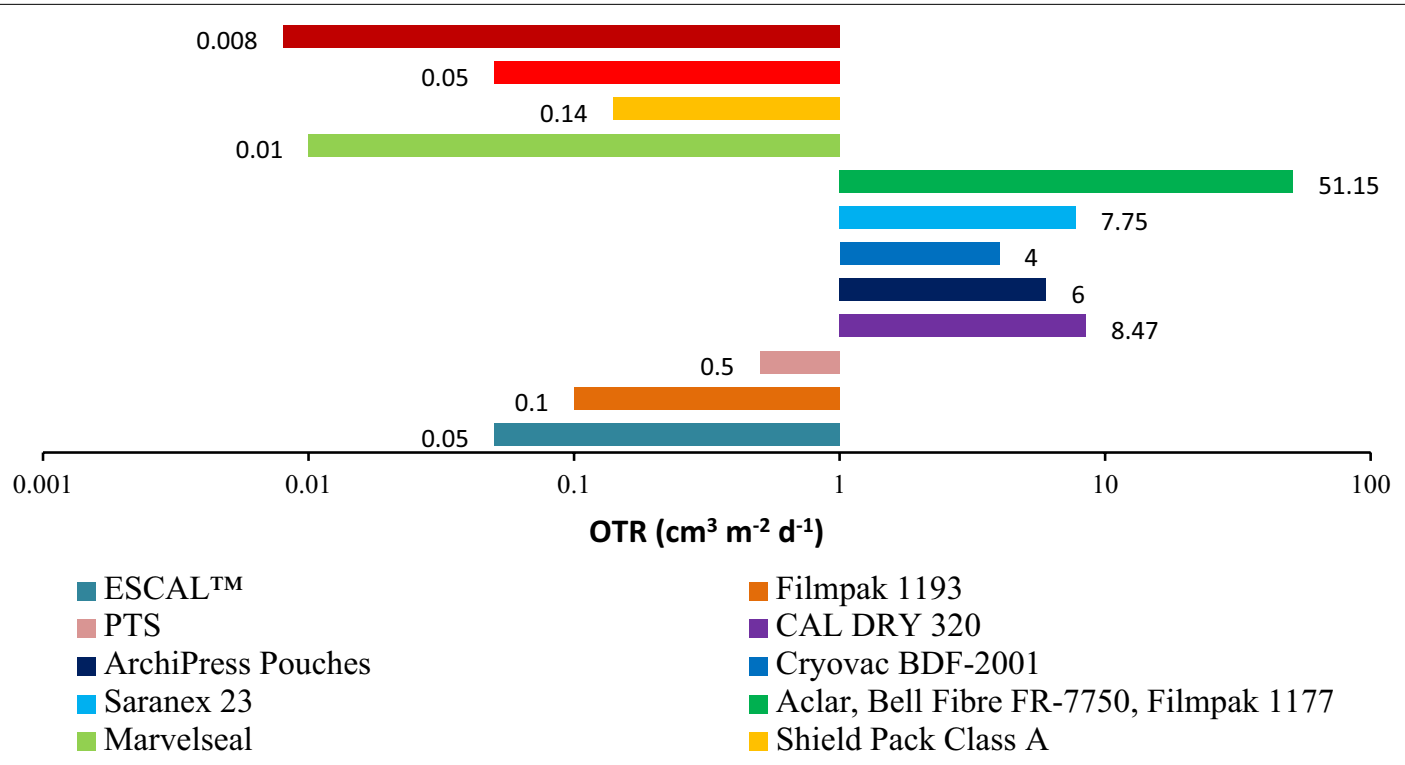

Fig. 1 Logarithm of Oxygen Transmission Rate (OTR) of the most used oxygen barriers (adapted from Elkhial [11]) 
ESCAL $^{\mathrm{TM}}$

ESCAL $^{\mathrm{TM}}$ is manufactured by Mitsubishi Gas Chemicals Inc., Japan, and is distributed worldwide. It is produced in sheet and tube rolls and sachets. ESCAL ${ }^{\mathrm{TM}}$ is ceramiccoated polyvinyl alcohol (PVAL). The basic structure for this barrier film is orientated polypropylene (OPP) as a surface layer, silica deposited polyvinyl alcohol $(\mathrm{SiO})_{\mathrm{x}}$ / PVAL as an intermediate layer, and linear low-density polyethylene (LLDPE) as an inner layer. It has superior oxygen and vapor barrier properties and its OTR is less than $0.1 \mathrm{~cm}^{3} \mathrm{~m}^{-2} \mathrm{~d}^{-1} \mathrm{~atm}^{-1}$ at $25{ }^{\circ} \mathrm{C}$ and $60 \% \mathrm{RH}$ [31]. It is optically very yellow and structurally thick $(114 \mu \mathrm{m})$ (Fig. 2a).

\section{Cross-barrier $^{\mathrm{TM}}$}

The laminate is manufactured by Nissin Kasei Co., Ltd., Saitama, Japan. It is produced in sheet rolls. Its thickness is $145 \mu \mathrm{m}$ and its weight is $115 \mathrm{~g} \mathrm{~m}^{-2}$. It was selected because it is a typical laminate consisting of three layers: a surface layer, an intermediate layer, and a backside layer. The surface layer consists of aluminum oxide $(\mathrm{ALO})_{\mathrm{x}}$ deposited on polyethylene terephthalate (PET). The intermediate reinforcement layer is typically made of polyethylene (PE). The back-side layer consists of linear low-density polyethylene (LLDPE). The composition ratio is approx. $13 \% \mathrm{PET}$, approx. $87 \% \mathrm{PE}$, and approx. $0.05 \%(\mathrm{ALO})_{\mathrm{x}}$ (Fig. 2b).

\section{Local commercial nylon film}

The laminate is manufactured by M2Pack Co., Cairo, Egypt. It is produced in different size sachets. The sachet used in this experiment measures $25 \times 30 \mathrm{~cm}$. Its thickness is $92 \mu \mathrm{m}$ and its weight is approx. $77.33 \mathrm{~g} \mathrm{~m}^{-2}$. It was selected because it is a low-cost, widely locally available laminate consisting of two layers, a surface layer, and an inner layer. The surface layer consists of polyamide (PA). The inner layer is typically made of linear low-density polyethylene (LLDPE). The interesting fact about this laminate is that it is recyclable (Fig. 2c).

\section{Test chamber}

The test system consisted of two well-sealed chambers: a source chamber and a collecting chamber. The chambers were long and cuboid to suit all grades of permeable films (high to low) [27, 28]. The adopted design from ASTM [30] was modified by constructing the chambers
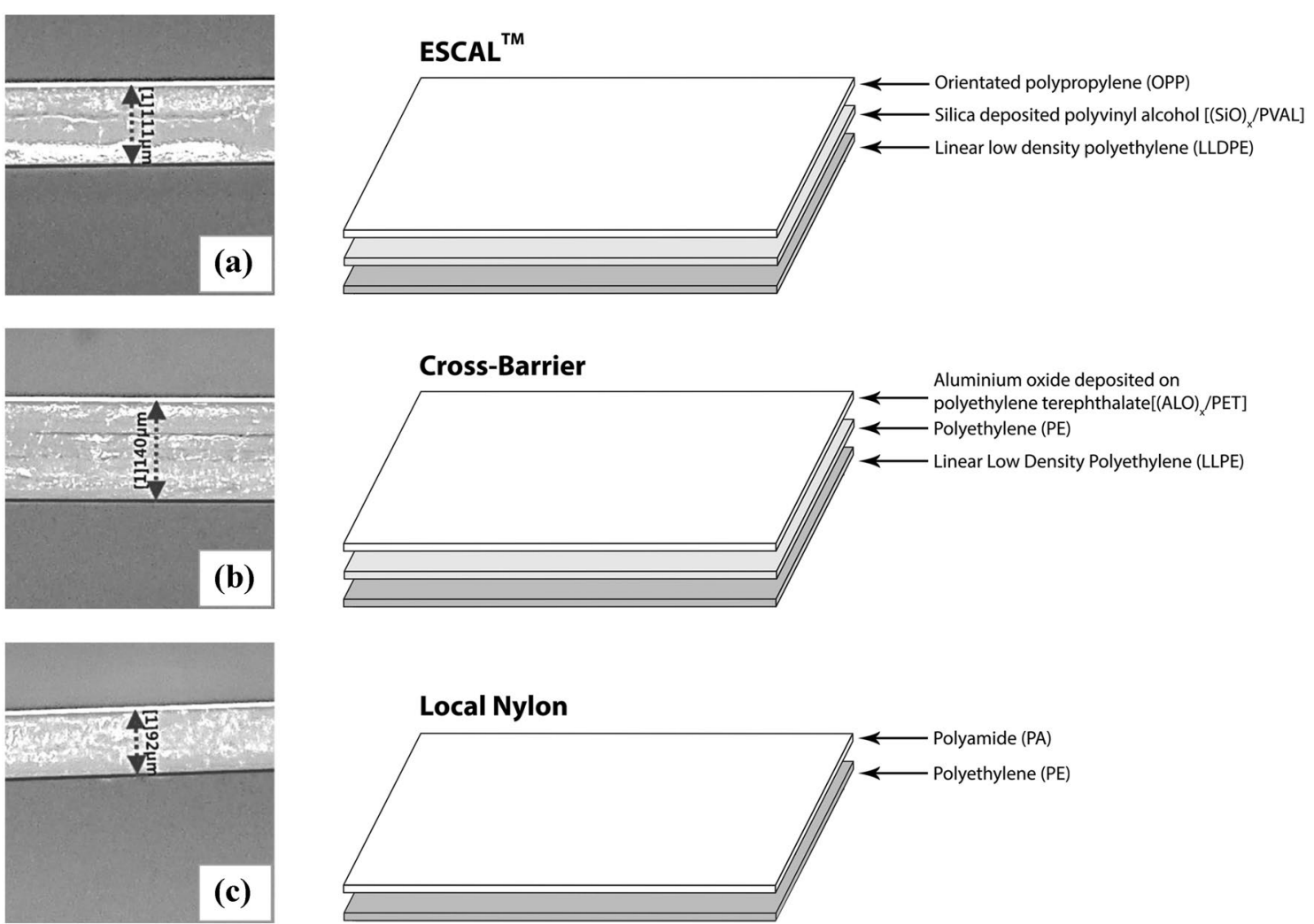

Fig. 2 Structure of laminates. On the left, cross-sections of laminates at optical microscope at magnification $\times 200$, with thicknesses in $\mu$ m. on the right, schemes of stratigraphic structures 
from $6 \mathrm{~mm}$-thick plexiglass (Spiroplastic S.A., Cairo, Egypt) sheets for the availability and workability of the material in conservation laboratories in museums. The chamber walls were glued using chloroform. Each chamber had an internal volume of $3 \mathrm{~L}(10 \times 10 \times 30 \mathrm{~cm})$, allowing a surface area of $100 \mathrm{~cm}^{2}$ to attach the laminate membrane. One end of each chamber was closed by gluing it to a $10 \times 10 \mathrm{~cm}$ piece of plexiglass. Holes with an $11-\mathrm{mm}$ diameter were drilled in the test chambers at the mid-point height as shown in Fig. 3 to create the inlet and sampling ports. The holes were fitted with one $1 / 4$ in brass male O-seal connector (Swagelok ${ }^{\circledR}$ Company, Ohio, United States) and sealed off to the outer surface of the acrylic sheet with a washer. The inlet port was connected to a $1 / 4$ in two-way brass ball valve (Swagelok ${ }^{\circledR}$ Company, Ohio, United States) to allow or shut off the gas purge process and enhance sealing after purge (Fig. 4). At the sampling ports, two septa (Ametek Mocon, Inc., Minnesota, United States) were fixed and plugged with a $1 / 4$ in brass plug (Swagelok ${ }^{\circledR}$ Company, Ohio, United States) for sealing off the port (Fig. 5).

\section{Selection and source of inert gas}

Nitrogen was selected as the inert fumigant in this experiment because it is the most utilized MIA gas and the most difficult to maintain at the same time. The gas was obtained from a high-pressure prepurified T-size cylinder equipped with a Mujelli OX - AC one-stage regulator (GCE Group, Malmö, Sweden) with a built-in flow meter [11].

\section{Experimental procedure Installation of laminates}

The tested film was glued to the open side of one chamber using epoxy glue mixed with its hardener and spread as a thin layer onto the 6-mm rim of the open side. After drying, a small amount of epoxy glue was evenly spread

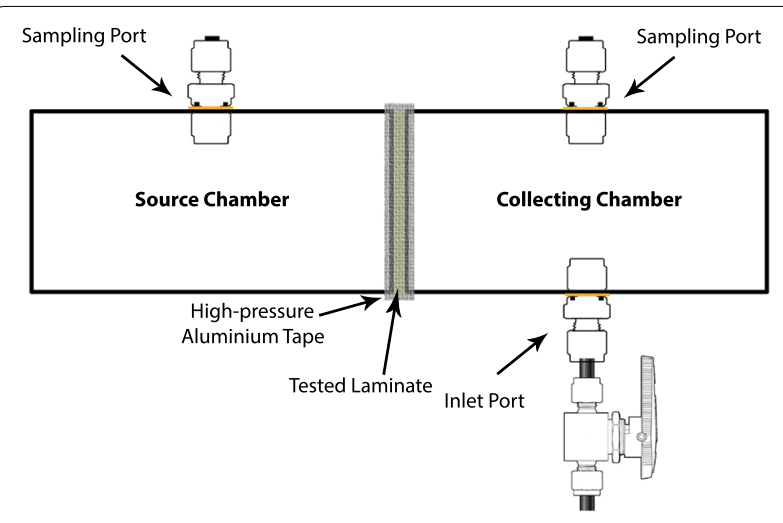

Fig. 3 Scheme of the test system: a side view

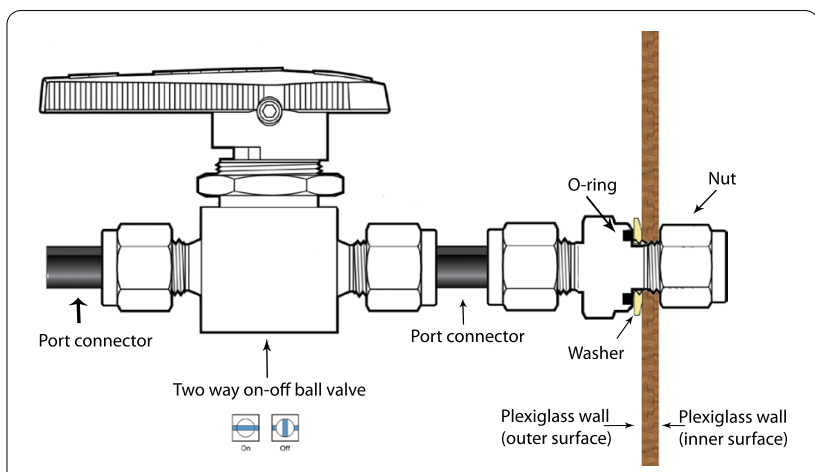

Fig. 4 Scheme of the inlet port fittings

onto the rim of the other chamber that was directly placed onto the test film aligning and joining the two chambers together with the test film in the middle. The contact line between the two chambers was later tapped with a 2-cm wide strip of high-pressure aluminum tape to guarantee tight sealing.

After installation, the film laminates were conditioned for a minimum of $40 \mathrm{~h}$ at standard laboratory conditions $\left(23 \pm 2{ }^{\circ} \mathrm{C}\right.$ and $\left.50 \pm 5 \% \mathrm{RH}\right)$ immediately before testing according to ASTM D618-05 [32]. The conditions were controlled and monitored using the heating ventilation and air conditioning (HVAC) system of the fumigation laboratory, where the tests were performed.

\section{Gas purge sampling and analysis}

The source chamber was purged with pure, dry $\mathrm{N}_{2}$ gas, following the dynamic purge process described by Elkhial [11], through the inlet port. After reaching $100 \% \mathrm{~N}_{2}$, the septa and plug were installed at the sampling port, followed by a quick shutdown of the ball valve then the gas

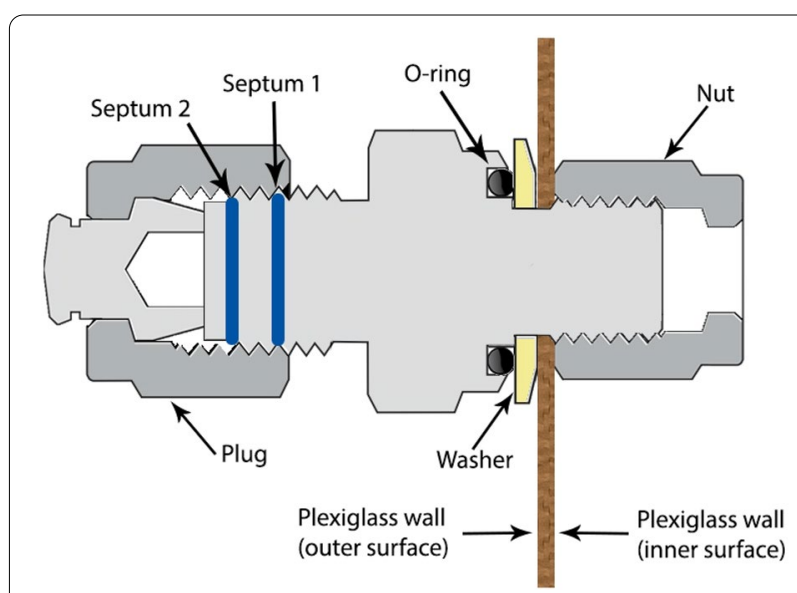

Fig. 5 Scheme of the sampling port fittings 
regulator to avoid pressure build-up and guarantee an $\mathrm{O}_{2}$-free gas path.

The concentration of $\mathrm{N}_{2}$ was measured by monitoring the concentration of $\mathrm{O}_{2}$ inside the bag using Dansensor ${ }^{\circledR}$ Checkmate $^{\circledR} 3$ Headspace $\mathrm{O}_{2}$ analyzer (Ametek Mocon, Inc., United States), measuring range $0-100 \%$, accuracy $\pm 0.01 \%$, and measuring three numbers after the decimal point. The utilized $\mathrm{O}_{2}$ sensor uses the latest zirconia $\mathrm{O}_{2}$ sensor, which has the inherent benefits of low cost, fast response, high sensitivity [33], and feedback control $[34,35]$. The analyzer was calibrated using fresh air at $20.946 \% \mathrm{O}_{2}$.

\section{Calculations and data processing}

The oxygen permeability can be measured by a series of mathematical equations as given in many publications $[27,28,30]$. However, the standard provided a Windowsbased software program, FilmPC (U.S. Department of Agriculture, California, United States), to facilitate the calculations by automatically solving the associated mathematical equations using a nonlinear least squares algorithm described by Marquardt [36] to obtain the parameters and statistics. To obtain the results in this study, FilmPC software, version 3.0.4, 2011 [37], was provided with the sampling time and concentration for each chamber sampled at the same time of the day. The initial concentration of oxygen in the source chamber was $0 \%$. The initial value of oxygen in the collecting chamber was $20.9 \%$, normalized to $100 \%$ in the graphs, and the loss of oxygen over time due to the transmission was recorded as the collecting chamber concentrations. After obtaining the results from the software, the OTR was calculated as it represents the permeability of oxygen over time through $1 \mathrm{~m}^{2}$ area of the film at specified conditions of temperature and relative humidity following the equation:

$$
O T R=\frac{Q}{A t}
$$

where $Q$ is the amount of permeant passing through the polymer $\left(\mathrm{cm}^{3}\right), A$ is the area $\left(\mathrm{m}^{2}\right)$ and $t$ is the time (d) [38].

\section{Results and discussion}

The oxygen permeability of three laminates was measured using a modified design of the test chamber approved by ASTM $[29,30]$ resulted in a completely airtight system and allowed for measuring very low oxygen permeability values. The oxygen permeability of the tested area of ESCAL $^{\mathrm{TM}}$ laminate was $0.00058 \pm 0.0001 \mathrm{~cm} \mathrm{~d}^{-1}$ (Figs. 6 and 7). The calculated OTR for a square meter is 0.06 $\mathrm{cm}^{3} \mathrm{~m}^{-2} \mathrm{~d}^{-1}$. Cross-Barrier data showed an oxygen permeability of the tested area of $0.02031 \pm 0.0002 \mathrm{~cm} \mathrm{~d}^{-1}$ (Figs. 8 and 9) with calculated OTR for a square meter of $2 \mathrm{~cm}^{3} \mathrm{~m}^{-2} \mathrm{~d}^{-1}$. Nylon, however, showed oxygen permeability of $0.04094 \pm 0.0005 \mathrm{~cm} \mathrm{~d}^{-1}$ (Figs. 10 and 11), with a calculated OTR of $4.1 \mathrm{~cm}^{3} \mathrm{~m}^{-2} \mathrm{~d}^{-1}$. The oxygen permeability graph of double-layered Nylon showed a rate of $0.01925 \pm 0.003 \mathrm{~cm} \mathrm{~d}^{-1}$ of oxygen permeability which corresponds to $1.9 \mathrm{~cm}^{3} \mathrm{~m}^{-2} \mathrm{~d}^{-1}$ OTR (Figs. 12 and 13).

Comparing the resultant OTR values of the tested laminates, the present study demonstrated the ultrahigh oxygen barrier property of ESCAL ${ }^{\mathrm{TM}}$. The measured OTR of Nylon film showed that it is of exceptional quality, as generally the OTR of polyamides ranges from 18 to $40 \mathrm{~cm}^{3} \mathrm{~m}^{-2} \mathrm{~d}^{-1}$ ([40] and goes up to $60[39,41]$ or 110

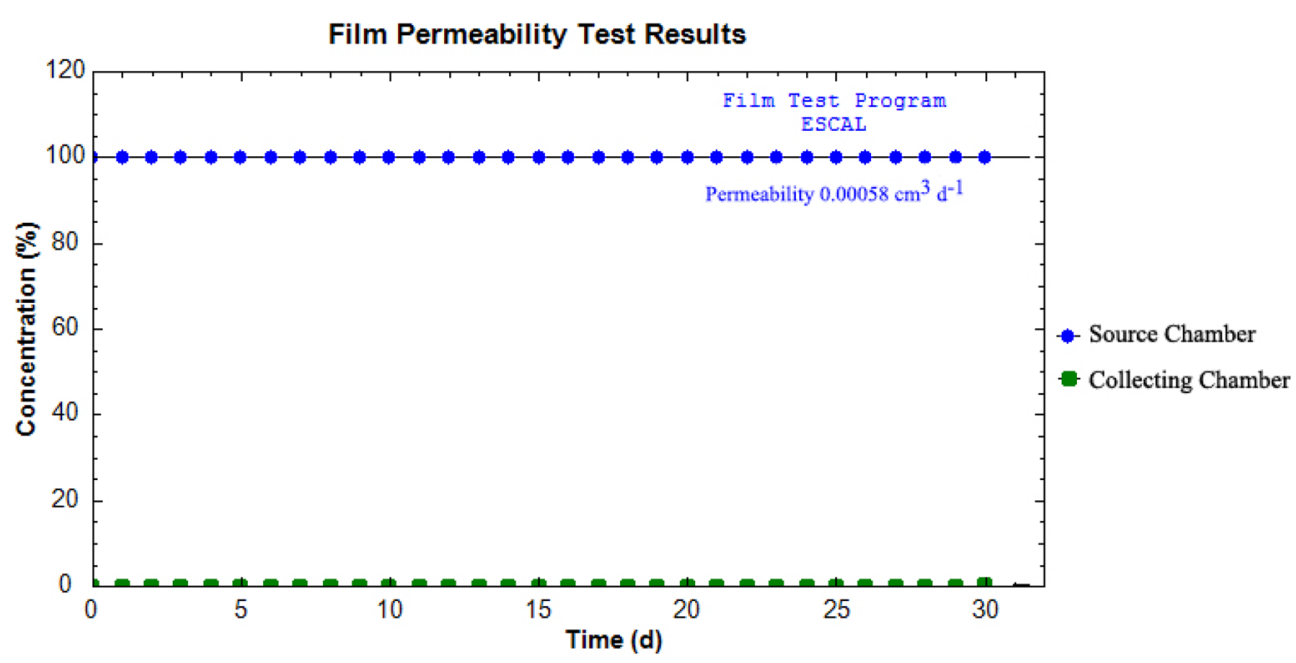

Fig. 6 ESCAL ${ }^{\mathrm{TM}} \mathrm{O}_{2}$ permeability analysis obtained from FilmPC software 


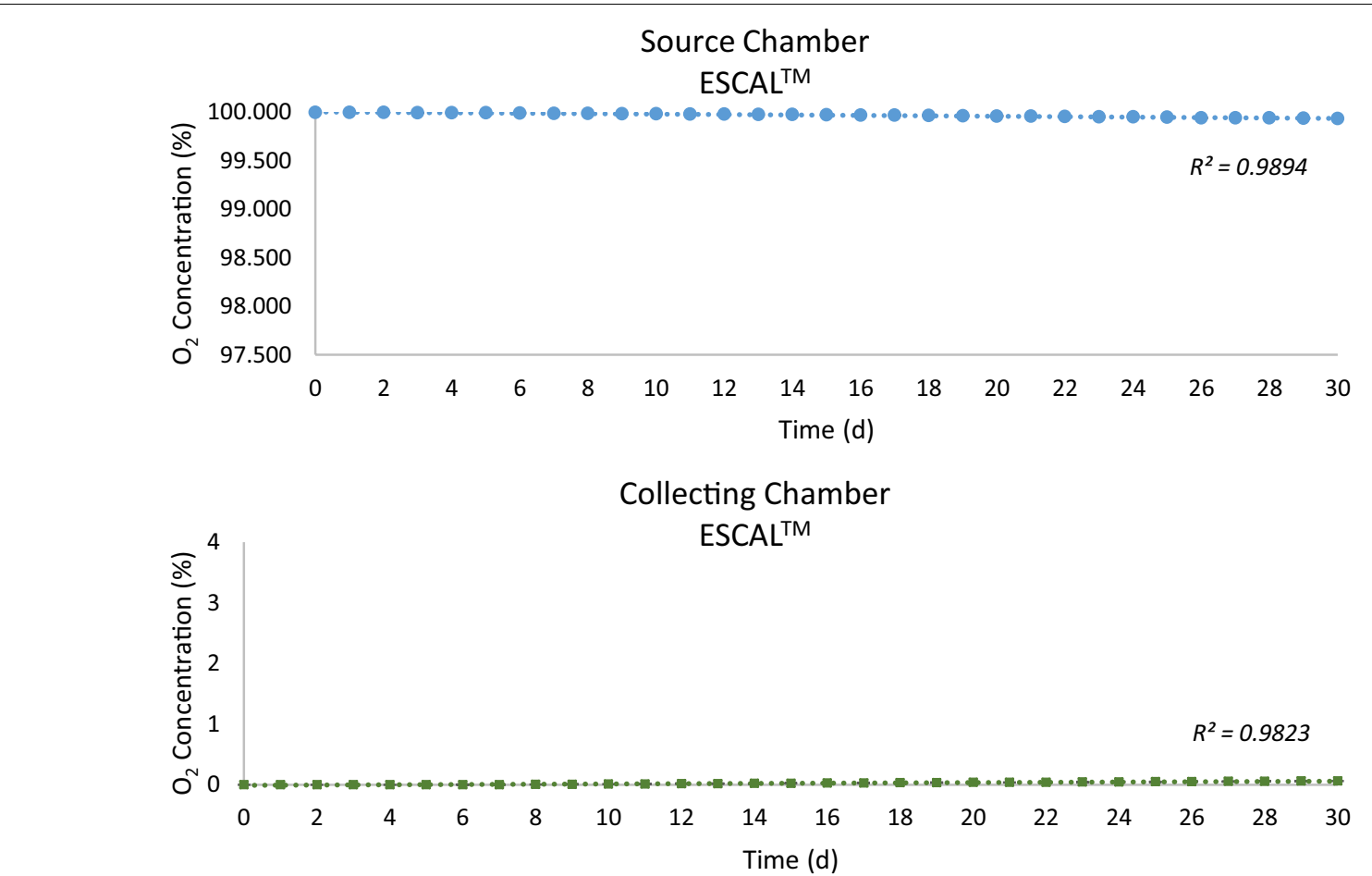

Fig. 7 Details on the source and collection chamber measurements during testing ESCAL ${ }^{\mathrm{TM}}$ laminate

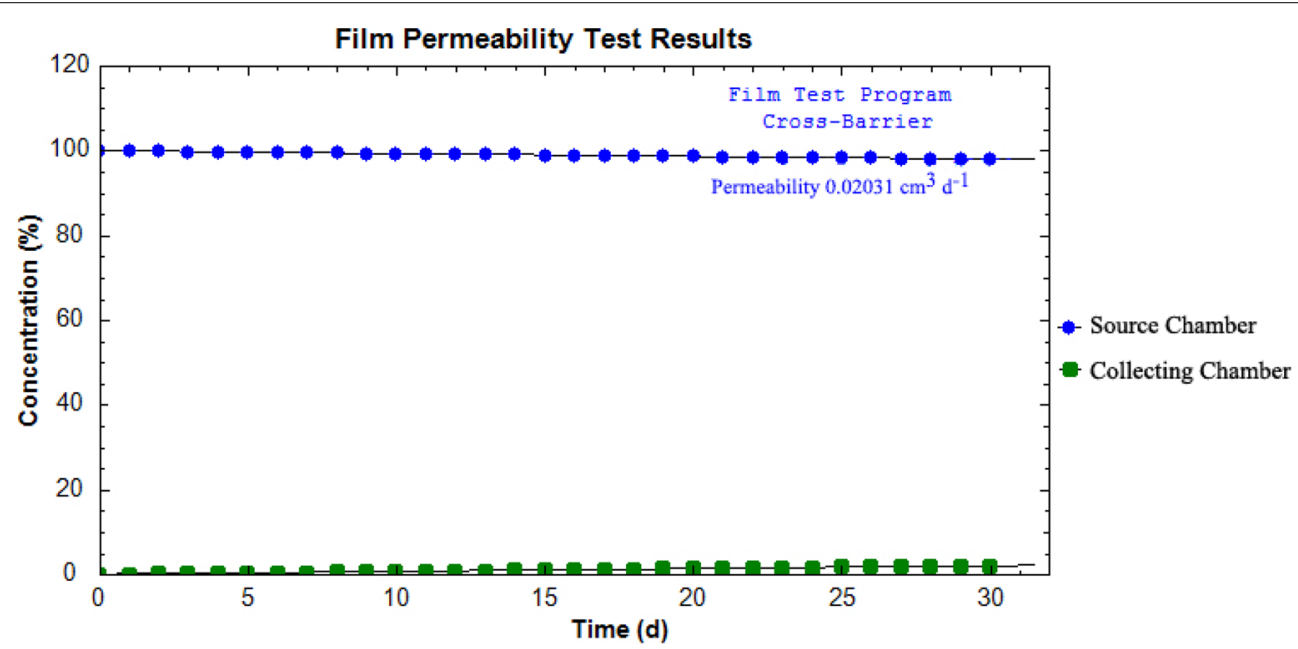

Fig. 8 Cross-Barrier $\mathrm{O}_{2}$ permeability analysis obtained from FilmPC software

$\mathrm{cm}^{3} \mathrm{~m}^{-2} \mathrm{~d}^{-1}$ [12, 42]. A superior result, however, was achieved by doubling the layer of Nylon, proposing it as a promising alternative to the expensive laminates. The cost of the doubled laminate was still far less than the cost of a single layer of the imported laminates (Table 1).

The methodological approach for testing the OTR of the film laminates is fairly straightforward and comes up with good results. The chambers are easy to create and assemble and could be easily replicated using any inert, leak-proof materials. Additionally, the analyzer is easy to use, normally available in museums that apply MIA treatments, and available in modern versions to measure oxygen and carbon dioxide at the same time, allowing for performing two tests at once. The only apparent concern about using this system could be the possibility of having leakage areas in the 

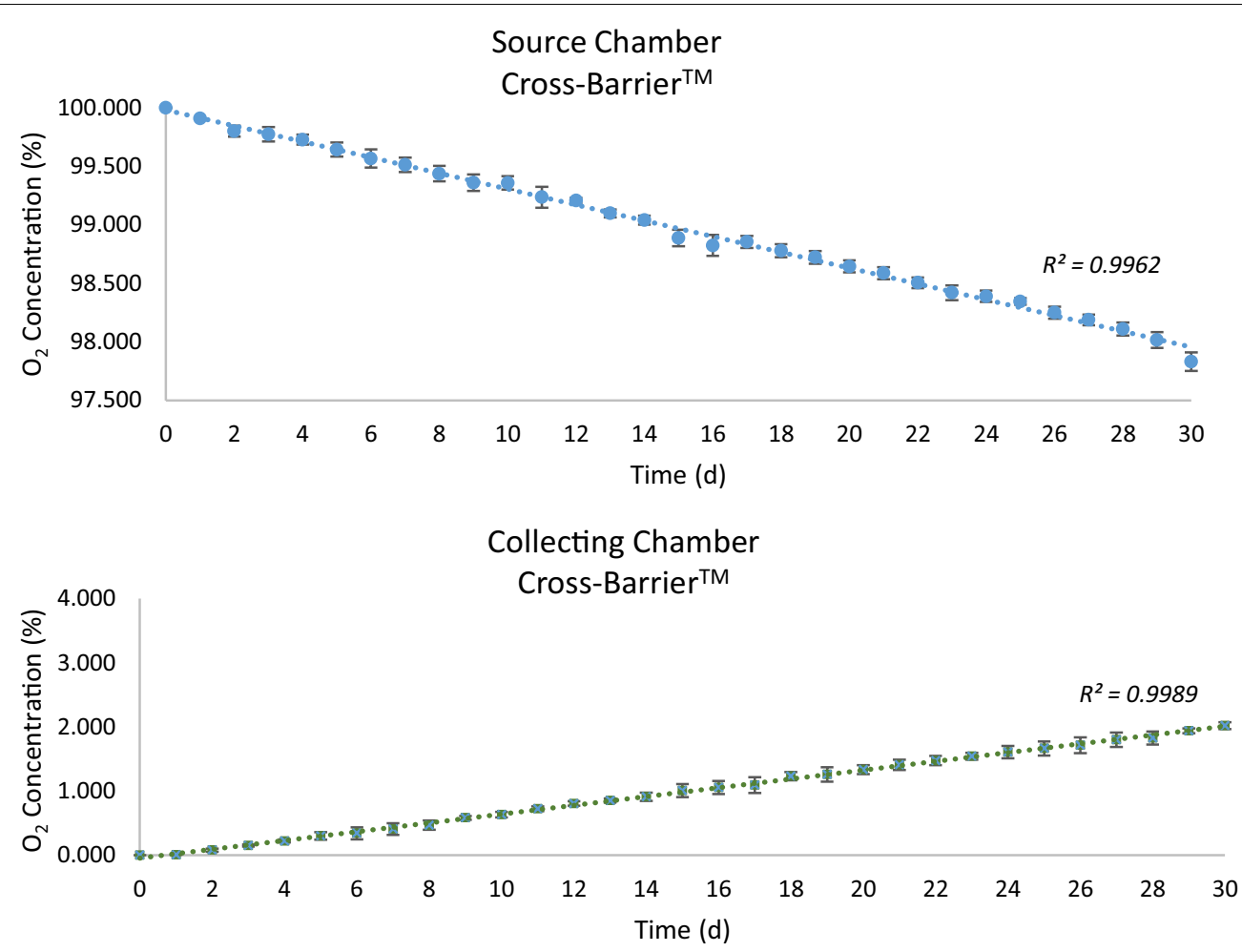

Fig. 9 Details on the source and collection chamber measurements during testing Cross-Barrier laminate

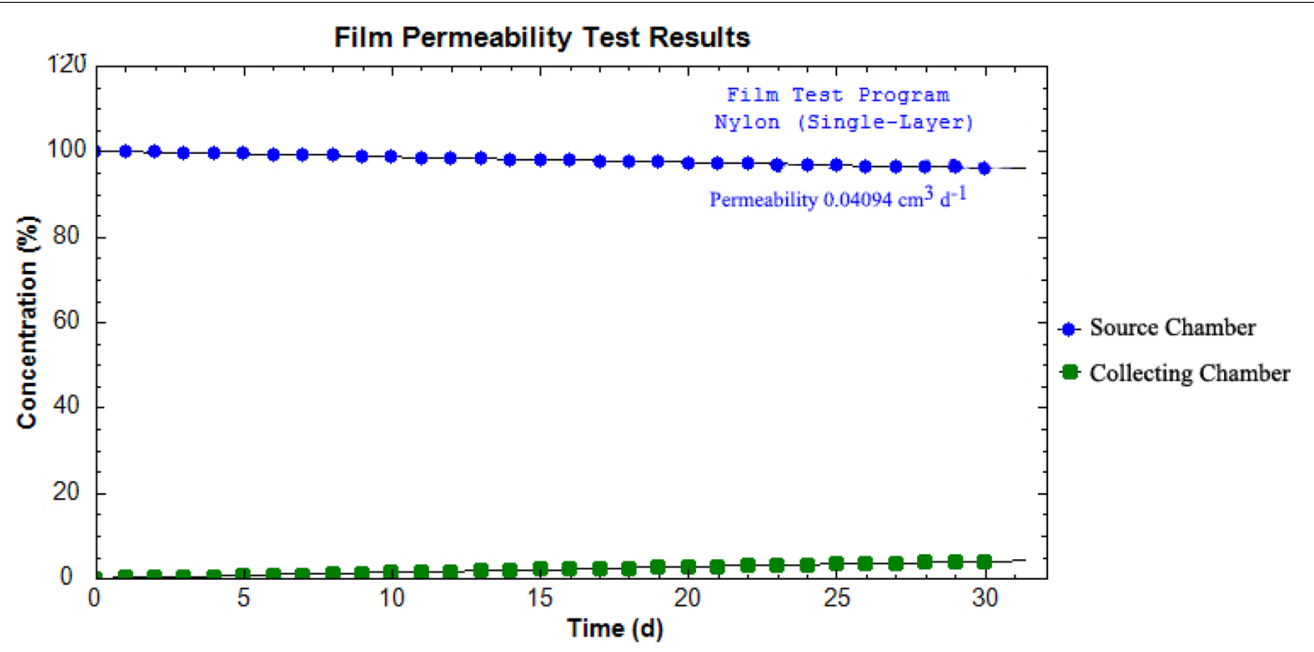

Fig. 10 Nylon $\mathrm{O}_{2}$ permeability analysis obtained from FilmPC software

system. Therefore, one must make sure that the whole system (materials, connections, joints, paths, etc.) is leak-proof. For precise data analysis, experiments should be iterated.

\section{Conclusion}

The selection of consumable laminates is the main challenge when applying MIA treatments as they should meet some criteria to guarantee successful treatments 

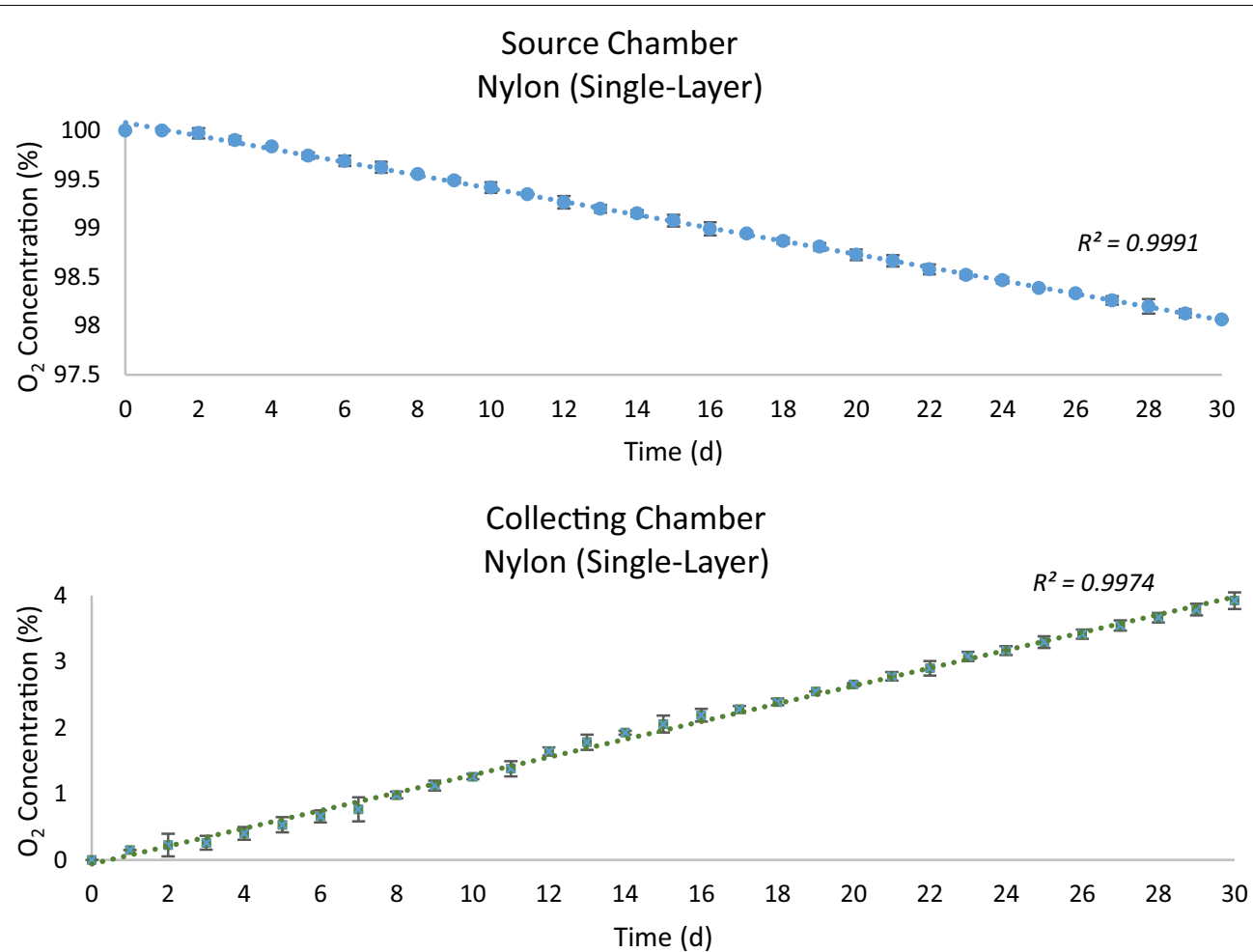

Fig. 11 Details on the source and collection chamber measurements during testing Nylon laminate

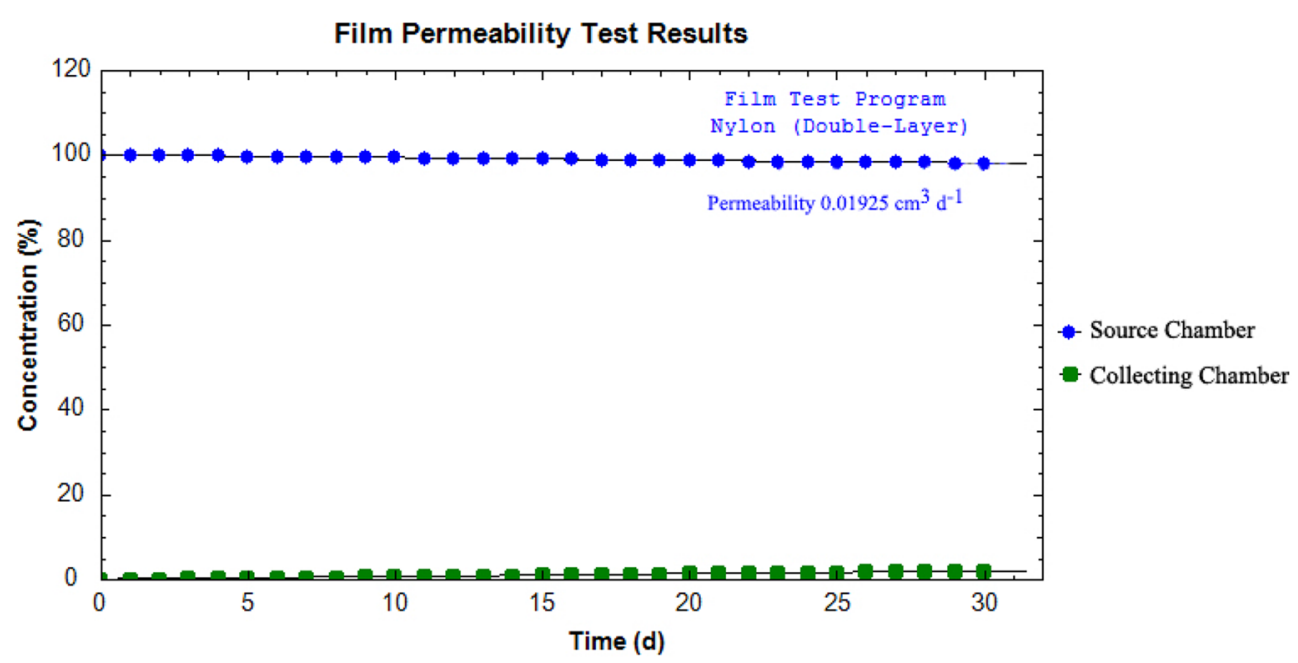

Fig. 12 Double-layer Nylon $\mathrm{O}_{2}$ permeability analysis obtained from FilmPC software

and be at acceptable costs to ensure sustainable application of the treatment, especially in limited-budget museums around the world.

In this study, a methodological approach adopted from the ASTM E2945-14 [15, 16] was developed to measure the oxygen permeability, and consequently, the OTR, of film laminates. The developed test system allows for an unlimited number of tests on an unlimited number of laminates using materials and equipment normally available in MIA laboratories, such as oxygen sensors, leak-proof fittings, and glass or thick plexiglass. The system allows for easy consistent, and time-managed OTR 


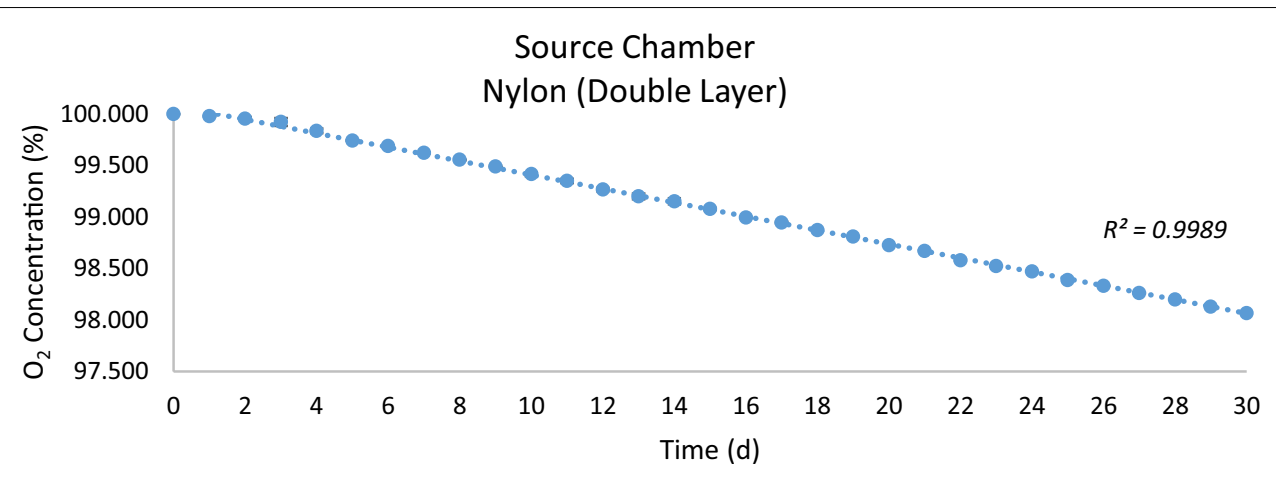

Collecting Chamber

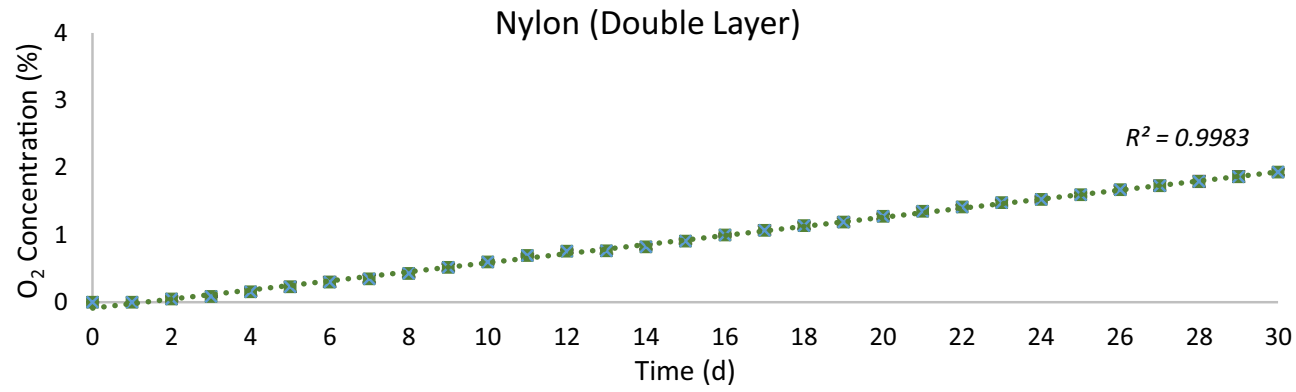

Fig. 13 Details on the source and collection chamber measurements during testing double-layer Nylon laminate

Table 1 Properties of tested laminated films. Price is given three grades for comparison

\begin{tabular}{|c|c|c|c|c|c|c|}
\hline \multirow[t]{2}{*}{ Film Laminate } & \multirow[t]{2}{*}{ Manufacturer } & \multirow[t]{2}{*}{ Composition } & \multirow[t]{2}{*}{ Thickness (mm) } & \multicolumn{2}{|c|}{ OTR $\left(\mathrm{cm}^{3} \mathrm{~m}^{-2} \mathrm{~d}^{-1}\right)$} & \multirow[t]{2}{*}{ Price $/ \mathrm{m}^{2}$} \\
\hline & & & & Spec & Meas & \\
\hline $\mathrm{ESCAL}^{\mathrm{TM}}$ & Mitsubishi Gas Chemical Co., Japan & $\begin{array}{l}(\mathrm{SiO})_{x} / \mathrm{PET} \\
\mathrm{PE}\end{array}$ & $0.11-0.12$ & $\begin{array}{l}<0.1[7] \\
0.05[12]\end{array}$ & 0.06 & Very high \\
\hline Cross-Barrier & Nissin Kasei Co., Ltd., Japan & $\begin{array}{l}(\mathrm{AlO})_{x} / \mathrm{PET} \\
\mathrm{PE} \\
\mathrm{LLDP}\end{array}$ & 0.14 & NA & 2.0 & Moderate \\
\hline Nylon & M2Pack Co., Cairo, Egypt & $\begin{array}{l}\text { PA } \\
P E\end{array}$ & 0.092 & NA & 4.1 & Low \\
\hline Double-Layer Nylon & & Alternate PA/PE & 0.184 & NA & 1.9 & Low \\
\hline
\end{tabular}

testing in museum laboratories. It also facilitates the selection among different laminates for MIA treatments to manage the cost and enhance the sustainability of their application and hereby accomplishes the main aim of this study.

Three different laminates were tested in this study. Results showed that ESCAL ${ }^{\mathrm{TM}}$ laminate, which is based on silicon dioxide, has the highest oxygen-barrier ability. Cross-Barrier, which is based on aluminum oxide, has almost the same OTR as double-layered Nylon, which is based on alternate polyamide/polyethylene layers. Although Nylon by default has the lowest OTR compared to other tested laminates, the tested local type showed high oxygen barrier properties which adds to its improved flexibility, due to its thickness and lack of strengthening layers. Furthermore, its competitive price and local availability make it a suitable choice for wide-range, sustainable MIA applications in limitedbudget museums worldwide.

\section{Abbreviations}

MIA: Modified inert atmosphere; OTR: Oxygen transmission rate; ASTM: International standards organization, formerly American Society for Testing and Materials; PVAL: Polyvinyl alcohol; OPP: Orientated polypropylene; LLDPE: Linear low-density polyethylene; PE: Polyethylene. 


\section{Acknowledgements}

The experiments were performed at the Fumigation Laboratory at the Grand Egyptian Museum. The authors are grateful for the scientific research encouragement by the GEM which allowed for using the laboratory facilities and equipment. We are especially grateful to Dr. Hussein Kamal, General Director of the Conservation Centre, for facilitating this work and for his useful advice.

\section{Authors' contributions}

Conceptualization, methodology, experiment, validation, analysis, discussions and writing- ME, supervision, writing-review and editing-NE. Both authors read and approved the final manuscript.

\section{Funding}

Not applicable.

\section{Availability of data and materials}

The datasets used and/or analyzed during the current study are available from the corresponding author on reasonable request.

\section{Declarations}

\section{Competing interests}

The authors declare that they have no competing interests.

\section{Author details}

${ }^{1}$ Conservation Center, The Grand Egyptian Museum, Al Haram, Giza Governorate, Egypt. ${ }^{2}$ Conservation Department, Faculty of Archaeology, Cairo University, Giza, Egypt.

Received: 16 October 2021 Accepted: 4 February 2022

Published online: 21 February 2022

\section{References}

1. Gulotta D, Fermo P, Toniolo L, Goidanich S. Anoxic treatment for the disinfestation of wood cultural heritage: assessment of the effects and harmfulness on different species. Wood Sci Technol. 2015;49:5. https:// doi.org/10.1007/s00226-015-0748-2.

2. Dias VS, Hallman GJ, Martínez-Barrera OY, Hurtado NV, Cardoso AAS, Parker AG, et al. Modified atmosphere does not reduce the efficacy of phytosanitary irradiation doses recommended for tephritid fruit flies. Insects. 2020;11:6. https://doi.org/10.3390/insects 11060371.

3. Valentin N. Comparative analysis of insect control by nitrogen, argon and carbon dioxide in museum, archive and herbarium collections. Int Biodeterior Biodegrad. 1993;32(4):263-78. https://doi.org/10.1016/09648305(93)90029-2.

4. Dionisi-Vici P, Tsukada M. Real-time evaluation of the efficacy of anoxic treatment for Cultural Heritage objects. Sci Int Rev. 2014;126:126. https:// doi.org/10.12969/Scientia.Vol126.Sect2.Art02.

5. Cao Y, Xu K, Zhu X, Bai Y, Yang W, Li C. Role of modified atmosphere in pest control and mechanism of its effect on insects. Front Physiol. 2019;10:206. https://doi.org/10.3389/fphys.2019.00206.

6. Njoroge AW, Mankin RW, Smith B, Baributsa D. Effects of hypoxia on acoustic activity of two stored-product pests, adult emergence, and grain quality. J Econ Entomol. 2019;112(4):1989-96. https://doi.org/10.1093/ jee/toz110.

7. High KE, Penkman KEH. A review of analytical methods for assessing preservation in waterlogged archaeological wood and their application in practice. Herit Sci. 2020;8:83. https://doi.org/10.1186/s40494-020-00422-y.

8. Lønnve J. Oxygen absorbers in practical conservation: a joint project between Swedish museums. In: Koskivirta R, editor. Conservation without limits: IIC Nordic Group XV Congress, August 23-26, 2000. Helsinki, Finland: IIC Nordic Group; 2000. p. 131-6.

9. Beltran VL, Druzik J, Maekawa S. Large-scale assessment of light-induced color change in air and anoxic environments. Stud Conserv. 2012;57:1. https://doi.org/10.1179/2047058411Y.0000000006.

10. Trematerra P, Pinniger D. Museum pests-cultural heritage pests. In: Athanassiou C, Arthur F, editors. Recent Advances in Stored Product
Protection. Berlin, Heidelberg: Springer; 2018. p. 229-260. https://doi.org/ 10.1007/978-3-662-56125-6_11.

11. Elkhial MM. Study on some operational problems of modified inert atmosphere fumigation and their solutions applied on a selected wooden artifact. MA [thesis]. Giza: Cairo University; 2019.

12. Maekawa S, Elert K. The use of oxygen-free environments in the control of museum insect pests. Los Angeles: Getty Publications; 2003.

13. Fereydoon M, Ebnesajjad S. Development of high-barrier film for food packaging. In: Ebnesajjad S, editor. Plastic Films in Food Packaging: Materials, Technology and Applications. William Andrew; 2012. p. 71-92. https://doi.org/10.1016/B978-1-4557-3112-1.00005-3.

14. Hahladakis JN, Velis CA, Weber R, lacovidou E, Purnell P. An overview of chemical additives present in plastics: Migration, release, fate and environmental impact during their use, disposal and recycling. J Hazard Mater. 2018;344:179-99. https://doi.org/10.1016/j.jhazmat.2017.10.014.

15. Tyagi P, Salem KS, Hubbe MA, Pal L. Advances in barrier coatings and film technologies for achieving sustainable packaging of food products-a review. Trends Food Sci Technol. 2021;115:461-85. https://doi.org/10. 1016/j.tifs.2021.06.036.

16. Gaikwad KK, Singh S, Lee YS. A pyrogallol-coated modified LDPE film as an oxygen scavenging film for active packaging materials. Prog Org Coatings. 2017;111:186-95. https://doi.org/10.1016/j.porgcoat.2017.05.016.

17. Kim J, Oh S, Cho SM, Jun J, Kwak S. Oxygen barrier properties of polyketone/EVOH blend films and their resistance to moisture. J Appl Polym Sci. 2020;137:47. https://doi.org/10.1002/app.49537.

18. Startek K, Marczak J, Lukowiak A. Oxygen barrier enhancement of polymeric foil by sol-gel-derived hybrid silica layers. Polymer (Guildf). 2020;195: 122437. https://doi.org/10.1016/j.polymer.2020.122437.

19. Zabihzadeh Khajavi M, Ebrahimi A, Yousefi M, Ahmadi S, Farhoodi M, Mirza Alizadeh A, et al. Strategies for producing improved oxygen barrier materials appropriate for the food packaging sector. Food Eng Rev. 2020;12:346-63. https://doi.org/10.1007/s12393-020-09235-y.

20. Selwitz C, Maekawa S. Inert gases in the control of museum insect pests. California: The Getty Publications; 1998.

21. Kim HJ, An DS, Ahn GH, Lee DS. Effects of film and seal conditions on the package atmosphere and storage stability of 'Fuyu' sweet persimmons. J Food, Agric Environ. 2011;9(1):95-8.

22. Morris BA. Barrier. In: The science and technology of flexible packaging: Multilayer Films from Resin and Process to End Use. William Andrew; 2017. p. 259-308. https://doi.org/10.1016/B978-0-323-24273-8.00008-3.

23. Burke J. Anoxic microenvironment: a treatment for pest control. In: Conserve O Gram. Number 3/3. U.S.: National Park Service; 1999. p. 1-4.

24. Massey LK. Introduction. In: Permeability properties of plastics and elastomers: a guide to packaging and barrier materials. 2nd ed. William Andrew; 2003. p. 1-56. https://doi.org/10.1016/B978-188420797-6. 50002-4.

25. McKeen LW, Massey LK. Permeability properties of plastics and elastomers: a guide to packaging and barrier materials. Permeability Prop Plast Elastomers. 2012. https://doi.org/10.1016/C2010-0-66502-3.

26. Papiernik SK, Yates SR, Gan J. An approach for estimating the permeability of agricultural films. Environ Sci Technol. 2001;35(6):1240-6. https://doi. org/10.1021/es0014279.

27. Papiernik SK, Ernst FF, Yates SR. An apparatus for measuring the gas permeability of films. J Environ Qual. 2002;31(1):358-61. https://doi.org/ 10.2134/jeq2002.3580.

28. Papiernik SK, Yates SR, Chellemi DO. A standardized approach for estimating the permeability of plastic films to soil fumigants under various field and environmental conditions. J Environ Qual. 2011;40(5):1375-82. https://doi.org/10.2134/jeq2010.0118.

29. ASTM. Standard test method for film permeability determination using static permeability cells. In Pesticides, Antimicrobials, And Alternative Control Agents; Hazardous Substances and Oil Spill Response. ASTM International; 2014. (Annual Book of ASTM Standards; 11.05. https://doi. org/10.1520/E2945-14.

30. ASTM. Standard test method for film permeability determination using static permeability cells. In Pesticides, Antimicrobials, And Alternative Control Agents; Hazardous Substances and Oil Spill Response. ASTM International; 2021. (Annual Book of ASTM Standards; vol. 11.08). https:// doi.org/10.1520/E2945-14R21.

31. Long Life for Art. https://Ifa.eu/escal-neo.html. Accessed 12 Dec 2021. 
32. ASTM. Standard Practice for Conditioning Plastics for Testing. In: Plastics (I): C1147- D3159. ASTM International; 2005. (Annual Book of ASTM Standards; vol 08.01). https://doi.org/10.1520/D0618-05.

33. Luo Z, Xiao J, Xia F, Yang Y. Preparation and characterization of zirconia oxygen sensors. J Wuhan Univ Technol Mater Sci Ed. 2007;22(4):612-6. https://doi.org/10.1007/s11595-006-4612-y.

34. Luo Z, Xiao J, Xia F. Preparation and analysis of zirconia oxygen sensors. Trans Nonferrous Metals Soc China. 2006;16(Suppl 1):s82-7. https://doi. org/10.1016/S1003-6326(06)60148-9.

35. Shuk P. Process zirconia oxygen analyzer - state of art. Tech Mess. 2010;77(1):19-23. https://doi.org/10.1524/teme.2010.0003.

36. Marquardt DW. An algorithm for least-squares estimation of nonlinear parameters. J Soc Ind Appl Math. 1963;11(2):431-41.

37. FilmPC [Internet]. Washington DC: United States Department of Agriculture; 2011 [updated 2022 Jan 07; cited 2022 Jan 20]. https://data.nal.usda. gov/dataset/filmpc

38. Robertson GL. Packaging materials for biscuits and their influence on shelf life. In: Manley D, editor. Manley's Technology of Biscuits, Crackers and Cookies. 4th ed. Woodhead Publishing Limited; 2011. p. 247-267. doi:https://doi.org/10.1533/9780857093646.2.247.

39. Paine FA. Plastics. In The Packaging User's Handbook. Boston, MA: Springer; 2012. p. 102-120. https://doi.org/10.1007/978-1-4613-1483-7_7.

40. Robertson GL. Optical, mechanical and barrier properties of thermoplastic polymers. In: Food Packaging: Principles and Practice. 3rd ed. Boca Raton: CRC Press; 2012. p. 91-130. https://doi.org/10.1201/b21347.

41. Butler TI, Morris BA. PE-based multilayer film structures. In: Wagner JR, editor. Multilayer Flexible Packaging. William Andrew; 2010. p. 205-230. https://doi.org/10.1016/B978-0-8155-2021-4.10015-2.

42. Goswami TK, Mangaraj S. Advances in polymeric materials for modified atmosphere packaging (MAP). In: Lagarón JM, editor. Multifunctional and Nanoreinforced Polymers for Food Packaging. Woodhead Publishing; 2011. p. 163-242. https://doi.org/10.1533/9780857092786.1.163.

\section{Publisher's Note}

Springer Nature remains neutral with regard to jurisdictional claims in published maps and institutional affiliations.

\section{Submit your manuscript to a SpringerOpen ${ }^{\circ}$ journal and benefit from:}

- Convenient online submission

- Rigorous peer review

- Open access: articles freely available online

- High visibility within the field

- Retaining the copyright to your article 